\title{
PERSEPSI DAN POLA PERGERAKAN WISATAWAN DI KOTA YOGYAKARTA KASUS : KAWASAN MALIOBORO
}

\section{Tatang Salim, Deva Fosterharoldas Swasto}

Universitas Gadjah Mada (UGM) Yogyakarta, Indonesia

Email: tatang.salim@gmail.com,devafswasto@ugm.ac.id

\begin{tabular}{ll}
\hline INFO ARTIKEL & ABSTRAK \\
\hline Diterima & Pariwisata merupakan salah satu industri jasa yang \\
25 Desember 2021 & mengutamakan dan menciptakan tingkat kepuasan bagi \\
Direvisi & wisatawan. Provinsi Daerah Istimewa Yogyakarta miliki \\
05 Januari 2022 & banyak objek wisata yang memiliki karakteristik berbeda-beda \\
Disetujui & sehingga terjadinya perpindahan elemen antar lokasi. \\
15 Januari 2022 & perpindahan wisata dapat dilihat dari perubahan ruang, mulai \\
\hline Kata Kunci: & ruang privat menuju ruang publik. Ruang publik yang selalu \\
persepsi; pergerakan; & ramai dengan pengunjung wisatawan di kota Yogyakarta \\
wisatawan; kawasan & adalah kawasan Malioboro. Tujuan dari penelitian ini adalah \\
malioboro & mengidentifikasi persepsi dan pola pergerakan wisatawan dan \\
& faktor yang mempengaruhinya di kawasan Malioboro. \\
& Penelitian ini dilakukan dengan metode kualitatif dengan sifat \\
& penelitian deskriptif. Pengumpulan data dilakukan secara \\
& dengan observasi, wawancara dan pengamatan lapangan dalam \\
& kurun waktu tertentu. Sampel dipilih dengan teknik non- \\
& random purposive sampling yaitu wisatawan domestik yang \\
& mengunjungi kawasan Malioboro. Hasil analisis menunjukkan \\
& bahwa melakukan perjalanan dengan motivasi merelaksasi atau \\
& hiburan dari aktivitas keseharian. Perjalanan wisata di kawasan \\
& Malioboro dengan pola pergerakan multi pattern yaitu base site \\
dan stopover. Faktor yang mempengaruhi dalam wisata adalah & faktor pendorong yaitu escape, educational opportunity dan \\
faktor penarik yaitu destinasi, tingkat kemudahan.
\end{tabular}

\section{ABSTRACT}

Tourism is one of the service industries that prioritizes and creates a level of satisfaction for tourists. The Province of the Special Region of Yogyakarta has many tourist objects that have different characteristics so that elements move between locations. The movement of tourism can be seen from space changes, from private to public space. The public space that is always busy with tourist visitors in the city of Yogyakarta is the Malioboro area. The purpose of this study is to identify perceptions and patterns of tourist movement and the factors that influence them in the Malioboro area. This research was conducted using qualitative methods with descriptive research 
properties. Data was collected using observation, interviews, and field observations within a certain period. The sample was selected using a non-random purposive sampling technique, namely domestic tourists visiting the Malioboro area. The results of the analysis show that traveling with the motivation of relaxation or entertainment from daily activities. Travel in the Malioboro area with a multi-pattern movement pattern, Keywords: $\quad$ namely the base site and stopover. The influencing factors in perception; tourism are the driving factors, namely escape, educational movement; tourist; opportunity, and the pull factors, the destination, the level of malioboro area convenience.

\section{Pendahuluan}

Daerah Istimewa Yogyakarta (DIY) merupakan salah satu tujuan wisata paling terkenal di Indonesia, dan daya tariknya antara lain wisata budaya, wisata alam, dan wisata belanja. Tempat wisata yang terdapat di Daerah Istimewa Yogyakarta tidak hanya dikenal oleh wisatawan lokal, bahkan terkenal hingga wisatawan mancanegara. Unsur budaya, keunikan, keramahan, kenyamanan dan keindahan merupakan keunggulan yang dimiliki DIY. Pariwisata DIY dengan berbagai unsur membuat banyak orang ingin berkunjung ke Provinsi DIY.

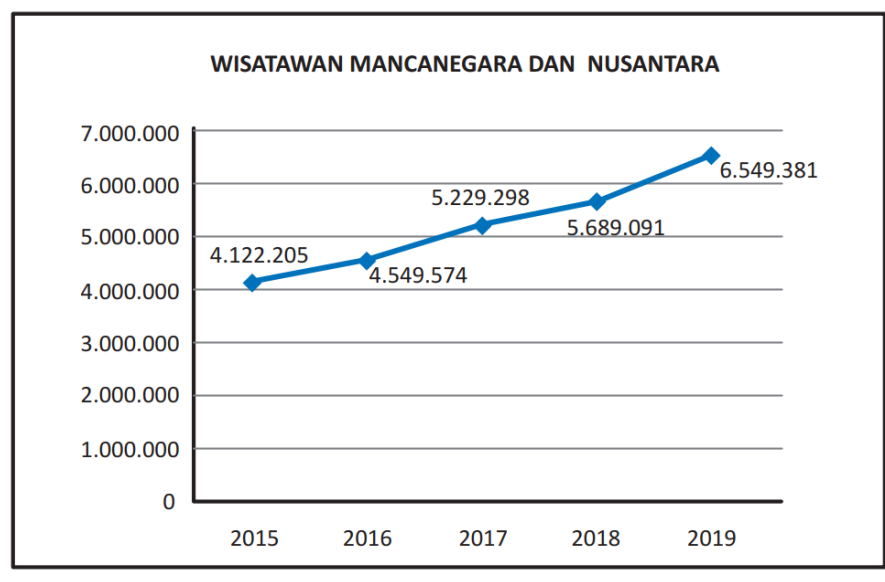

Gambar 1

Grafik Perkembangan Wisatawan ke D.I.Y Tahun 2015 -2019

Menurut statistik Dinas Pariwisata Daerah Istimewa Yogyakarta, jumlah yang berkunjung Daerah Istimewa Yogyakarta meningkat setiap tahunnya. Jumlah kunjungan oleh wisatawan mancanegara ke tempat objek wisata sebanyak 633.695 orang, sedangkan wisatawan nusantara mencapai 5.915 .686 orang, maka total wisatawan yang berkunjung ke DIY mencapai 6.549 .381 orang (DIY, 2019). Peningkatan jumlah pengunjung mancanegara tahun 2017 hingga 2018 meningkat sebanyak 18.421 orang dan wisatawan nusantara pada tahun 2017 hingga 2018 sebesar 441.372 orang. Sedangkan jumlah objek wisata di DIY tercatat pada tahun 2018 diantaranya objek 
wisata alam, objek wisata budaya, objek wisata buatan, desa/kampung wisata adalah sebanyak 185 objek wisata lainnya.

Daya tarik wisata (ODTW) tidak hanya tersebar di satu daerah, tetapi terdapat juga berbagai objek wisata yang ada di Provinsi Yogyakarta. Setiap daerah dan kota akan memberikan karakteristik yang berbeda-beda untuk setiap objek dan daya tarik wisatanya. Jarak transmisi antar objek dan daya tarik wisata yang terjangkau mendorong adanya fasilitas pendukung pariwisata seperti akomodasi tempat tinggal atau penginapan, dan hotel. Sarana penunjang pariwisata di Kota Yogyakarta yang lebih terpusat membuat migrasi dari akomodasi ke destinasi wisata semakin bergairah. Ini terkait erat dengan perpindahan elemen antar lokasi.

Biro Perjalanan Wisata terdapat divisi tour department yang terbagi menjadi 3 (Chaniago, 2015) yaitu domestic tour, inbound tour, outbound tour. Domestic tour dapat berarti perjalanan wisata lokal yang dilakukan oleh seseorang dengan tujuan daerah yang masih merupakan ruang lingkupnya di dalam suatu negara yang sama (Wisatawan Nusantara). Wisatawan domestik atau nusantara melakukan perjalanan rekreasi di negaranya untuk mengetahui sesuatu yang berbeda dari lingkungan sekitarnya. Tujuan wisatawan nusantara atau domestik adalah mengobati rasa penasaran suatu wisata menakjubkan. Kemajuan pariwisata juga mengalami perubahan baik segi pola pikir, minat dan keterkaitannya (Lusiana, 2012). Wisatawan tidak lagi hanya mencari kesenangan melainkan mulai peduli pada budaya, pendidikan sejarah, alam dan kelestariannya.

Pergerakan atau perpindahan wisatawan dapat dilihat dari perubahan ruang, ruang dimulai dari ruang penginapan menuju ruang publik atau objek wisata (Widyastuti et al., 2019). Perbedaan ruang dapat ditemukan pola pergerakan yang berbeda. Kota Yogyakarta secara administratif berbatasan dengan kabupaten yang memiliki tempat daya tarik wisata (DTW). Pengunjung yang datang ke Kota Yogyakarta juga dapat melakukan aktivitas di tempat wisata di luar Kota Yogyakarta.

Meningkatnya variasi objek wisata untuk menarik daya tarik wisatawan menyebabkan variasi pada perpindahan atau pergerakan wisatawan. Memahami pergerakan wisatawan maka dapat diketahui bahwa objek dan daya tarik wisata akan menurunkan kinerja kegiatan kepariwisataan, dan daya tarik wisata akan terlaksana dengan baik (Papilo, 2012). Keberagaman objek wisata dapat dipengaruhi oleh karakteristik wisatawan, terkadang kelompok atau individu yang memiliki minat atau hobi yang berbeda untuk jenis wisata. Sehingga dapat diketahui objek dan daya tarik wisata yang diminati oleh wisatawan di Yogyakarta serta menggambarkan kualitaskualitas dari objek wisata tersebut.

Kunjungan wisatawan yang terus meningkat tiap tahunnya di kawasan Malioboro sampai saat ini. Hal ini ditunjukkan dari banyaknya variasi objek wisata untuk menarik daya tarik wisatawan. Variasi objek wisata yang beraneka ragam di kawasan Malioboro terdiri wisata sejarah, pendidikan, belanja hingga kuliner. Keberagaman objek wisata mempengaruhi wisatawan untuk mengunjungi sehingga membuat persepsi wisatawan sikap penasaran. Sikap penasaran menentukan perilaku seseorang dalam hubungan 
dengan kejadian tertentu. Kejadian tersebut membuat pemusatan aktivitas di suatu area, sehinnga memberi berbagai dampak bagi pengunjung lainnya. Variasi-variasi objek daya tarik wisata mempengaruhi aktivitas wisatawan untuk berwisata. Hal ini akan membentuk perpindahan atau pergerakan wisatawan. Setiap pergerakan yang dipengaruhi perilaku wisatawan untuk berwisata.

Penelitian ini bertujuan untuk mengetahui persepsi dan pola pergerakan wisatawan domestik di kawasan Malioboro. Hasil dari penelitian ini diharapkan menjadi rekomendasi dalam pengembangan sarana prasana serta titik-titik objek wisata di kawasan Malioboro. Kelanjutan dari penelitian ini akan digunakan sebagai input dalam simulasi perilaku wisatawan dalam berwisata. Permodelan ini digunakan sebagai pendekatan perencanaan kawasan yang dapat menciptakan suasana yang memuaskan bagi wisatawan dalam kriteria pergerakan secara efisien dan efektif.

1. Persepsi

Istilah "persepsi" adalah proses aktivitas seseorang memberikan suatu penilaian, kesan, pendapat, perasaan dan penjelasan informasi ditampilkan berdasarkan sumber lain (Shafaruddin, 2013). Maka persepsi kita dapat mengenali tentang suatu daerah. Perbedaan antara lain, mengarah pada mengapa seseorang menyenangi sebuah objek, sedangkan yang lainnya tidak senang bahkan membencinya. masalah ini sangat tergantung pada reaksi pribadi pada objek tersebut. Faktanya, kebanyakan sikap, perilaku dan penyesuaian ditentukan oleh persepsi.

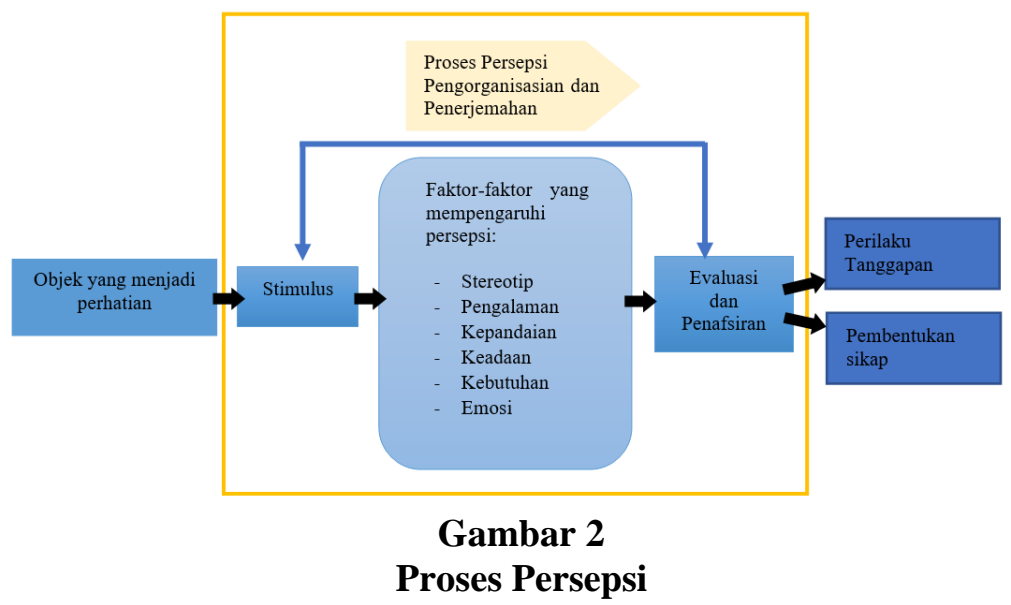

Persepsi yang sejatinya cenderung lebih bersifat psikologis daripada hanya merupakan proses penginderaan saja, maka ada beberapa faktor yang mempengaruhi, seperti perhatian yang selektif, individu memusatkan perhatiannya pada rangsangrangsang tertentu (Ramadhani, 2015). Terdapat proses persepsi, yaitu proses dimana seseorang mengenali dan merealisasikan suatu objek berdasarkan rangsangan yang mengenai organ inderanya.

2. Pola Pergerakan

Pola pergerakan dalam sistem transportasi terdiri dari 2 pola pergerakan, yaitu pola pergerakan spasial dan pola pergerakan non spasial (Ario Gesang, 2021). 
Konsep pada pergerakan spasial yang (batasan dengan ruang) berkaitan dengan sebaran spasial penggunaan lahan disuatu wilayah. Pada dasarnya perjalanan diperlukan melakukan kegiatan atau aktivitas tertentu di lokasi yang dituju dan lokasi ditentukan oleh tata guna lahan kota tersebut. Pola pergerakan spasial lebih mengarah kepada mengapa orang melakukan pergerakan, kapan orang melakukan pergerakan dan jenis angkutan apa yang digunakan oleh masyarakat untuk melakukan pergerakan (Dwi P, 2018). Lau \& McKercher dalam (Sukmaratri, 2013) mengemukakan bahwa pola pergerakan wisatawan terbagi menjadi 3 jenis, yaitu pola tunggal (single pattern), pola majemuk (multiple pattern), dan pola kompleks (complex pattern). Single pattern merupakan single point, multiple pattern terdiri atas base site, stopover, dan chaining loop. Sedangkan pola complex pattern terdiri atas destination region loop dan complex neighbourhood.

Tabel 1

Pola Pergerakan Wisatawan

\begin{tabular}{|c|c|c|}
\hline $\begin{array}{c}\text { Pola } \\
\text { Pergerakan }\end{array}$ & Jenis & Penjelasan \\
\hline Single Pattern & & $\begin{array}{l}\text { Pergerakan yang berpindah ke satu } \\
\text { titik tujuan tanpa harus mengunjungi } \\
\text { titik tujuan lainnya dan kembali } \\
\text { dengan rute yang sama }\end{array}$ \\
\hline Multiple Pattern & $\mathrm{Bas}$ & $\begin{array}{l}\text { Pergerakan menyerupai sebaran sinar } \\
\text { dengan satu titik pusat. Wisatawan } \\
\text { mulai dari tempat asalnya sampai ke } \\
\text { tujuan utama, kemudian dilanjutkan } \\
\text { kunjungan tujuan sekunder di daerah } \\
\text { tertentu. }\end{array}$ \\
\hline & & $\begin{array}{l}\text { Pergerakan dengan menuju tujuan } \\
\text { utama dan mengunjungi titik destinasi } \\
\text { lainnya (sekunder) } \\
\text { pergerakannya. }\end{array}$ \\
\hline & Loop & $\begin{array}{l}\text { Pergerakan dengan rotasi seperti ring } \\
\text { yang menghubungkan dua atau lebih } \\
\text { titik tujuan dan tidak mengulang rute } \\
\text { tersebut. }\end{array}$ \\
\hline $\begin{array}{l}\text { Complex } \\
\text { Pattern }\end{array}$ & $\begin{array}{c}\text { Destination region } \\
\text { loop }\end{array}$ & $\begin{array}{l}\text { Perjalanan wisatawan dimulai dari rute } \\
\text { keliling tujuan lain. Setelah } \\
\text { menyelesaikan tur secara melingkar, } \\
\text { wisatawan kembali ke tempat asal } \\
\text { pemberangkatan melalui jalur } \\
\text { terpendek antara tujuan utama dengan } \\
\text { tempat pemberangkatan. Pola ini } \\
\text { merupakan pola kombinasi dari satu } \\
\text { titik (single point) dan pola melingkar } \\
\text { yang terus berubah (changing loop). }\end{array}$ \\
\hline
\end{tabular}




$\begin{array}{cl}\begin{array}{c}\text { Complex } \\ \text { neighborhood }\end{array} & \begin{array}{l}\text { Pola yang memiliki pola kombinasi } \\ \text { yang terdiri dari dua pola atau lebih } \\ \text { pola. }\end{array}\end{array}$

Pergerakan wisatawan dengan menunjukkan adanya suatu pola spasial kegiatan wisata baik dari segi fisik maupun berkaitan dengan lingkungan. Pergerakan wisatawan dipengaruhi oleh kepentingan seseorang atau kelompok wisatawan untuk memenuhi kebutuhannya. Oleh karena itu kegiatan wisata dianggap berkelanjutan apabila telah memenuhi syarat yaitu secara ekologis, sosial, kebudayaan dan ekonomi yang menguntungkan (Suwena \& Widyatmaja, 2017). Faktor-faktor yang dapat mempengaruhi pergerakan wisatawan antara lain (Sofi \& Susilowati, 2017):

a. Faktor pendorong (push): pengaturan wisata, motivasi wisatawan, prioritas kunjungan, pengalaman berwisata.

b. Faktor penarik (pull): kondisi geomorfologi objek wisata, event, sarana prasaran.

c. Faktor waktu (time): lama tinggal di wisata, lama perjalanan, dana lama kunjungan di suatu objek wisata.

\section{Metode Penelitian}

Penelitian ini dilakukan dengan metode kualitatif (Arikunto, 2014) dengan sifat penelitian deskriptif (Sugiyono, 2016) yaitu dengan menguraikan serta menjelaskan persepsi dan pola pergerakan wisatawan rombongan kelompok dan keluarga di kawasan Malioboro.

Pengamatan dilakukan dengan survei dan observasi dalam kurun waktu Februari Maret 2020. Survei dilakukan dengan wawancara secara langsung dan observasi dilakukan dengan pemetaan dan dokumentasi terhadap kondisi lapangan. Populasi pada penelitian ini adalah masyarakat dan wisatawan domestik di kawasan Malioboro. Penelitian ini berfokus pada kawasan wisata Malioboro. Narasumber penelitian berupa wisatawan domestik dengan kategori rombongan keluarga dan rombongan kelompok. Jumlah responden dengan total 60 responden yang mewakili rombongan. Sampel dengan teknik non-random purposive sampling (Arikunto, 2014) yaitu wisatawan dengan rombongan keluarga dan rombongan kelompok yang mengunjungi wisata kawasan Malioboro.

Metode analisis data menggunakan teknik analisis kualitas (Siregar, 2016): faktual dan perseptual, yaitu menjelaskan kondisi faktual kasus dari hasil observasi yang didukung dengan persepsi wisatawan rombongan dari hasil wawancara. Analisis dilakukan dengan beberapa tahapan. Tahapan pertama dengan melakukan analisis berdasarkan teknik simulasi penelitian lanjutan. Tahapan berikutnya yaitu persepsi dan pemetaan pola pergerakan wisatawan rombongan berdasarkan hasil analisis tahap 
sebelumnya dan observasi secara langsung. Sehingga dapat identifikasi persepsi dan tipe pola pergerakan wisatawan.

\section{Hasil dan Pembahasan}

\section{A. Karakteristik Wisatawan}

Karakteristik kelompok wisatawan di Kawasan Malioboro Yogyakarta dapat dilihat dari provinsi asal wisatawan. Sebagian besar kelompok wisatawan yang mengunjungi kawasan Malioboro berasal dari Provinsi Jawa Barat (36 persen/22 kelompok). Ketertarikan kelompok wisatawan asal Provinsi Jawa Barat melakukan perjalanan ke Malioboro sangat tinggi terutama pada kelompok siswa. Selain Provinsi Jawa Barat, wisatawan dari DKI Jakarta (21 persen/13 kelompok), sedangkan wisatawan dari Provinsi Jawa Tengah (16 persen/10 kelompok), Provinsi Jawa Timur (9,8 persen/6 kelompok). Wisatawan yang berasal dari luar pulau Jawa (11 persen/7 kelompok). Hal ini mempengaruhi lama perjalanan wisata, lama berkunjung, dan banyak wisata yang di kunjungi.

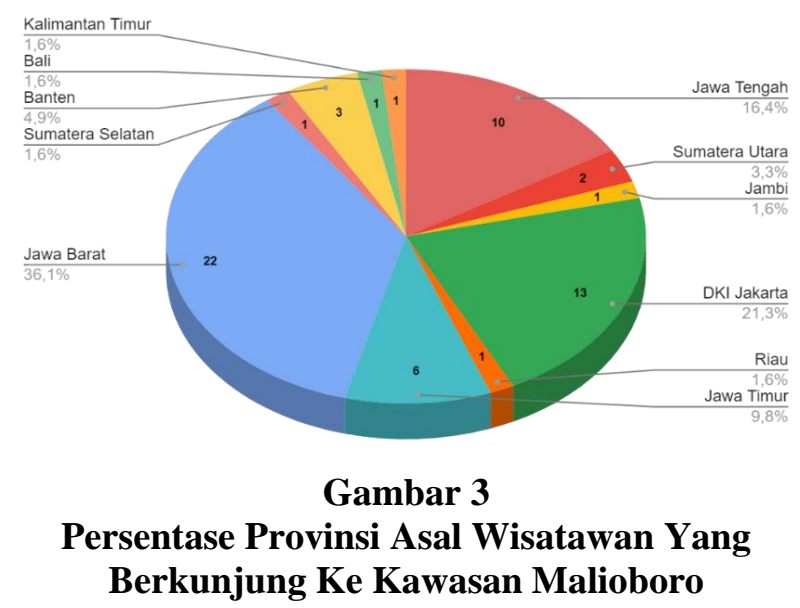

1. Karakteristik Wisatawan Berdasarkan Jenis Kelamin

Berdasarkan data di lapangan penelitian, dapat didistribusikan responden menurut jenis kelamin yang menjadi sampel dalam penelitian ini pada tabel 2 data responden wisatawan berdasarkan jenis kelamin dalam kedua kelompok.

Tabel 2

Data Responden Menurut Jenis Kelamin

\begin{tabular}{|c|c|c|c|c|c|}
\hline & \multicolumn{4}{|c|}{ Jenis Kelamin } & \multirow{3}{*}{ Total } \\
\hline & \multicolumn{2}{|c|}{ Laki-laki } & \multicolumn{2}{|c|}{ Perempuan } & \\
\hline & Jumlah & $\%$ & Jumlah & $\%$ & \\
\hline Keluarga & 16 & 53,33 & 14 & 46,67 & 30 \\
\hline Kelompok & 12 & 38,71 & 19 & 61,29 & 30 \\
\hline
\end{tabular}

Berdasarkan tabel diatas, menunjukkan bahwa responden dalam penelitian ini didominasi berjenis laki-laki pada wisatawan keluarga yang berperan sebagai kepala keluarga dengan jumlah 16 orang $(53,3 \%)$ dan berjenis perempuan dengan 
jumlah 14 orang $(46,7 \%)$. Kepala keluarga yang dimaksud disini adalah orang yang memimpin dan menentukan wisata yang akan dikunjungi. Sedangkan responden pada wisatawan kelompok lebih dominasi pada berjenis perempuan dengan jumlah19 orang $(61,3 \%)$ dan jenis laki-laki sejumlah 12 orang $(38,7 \%)$.

2. Lama kunjungan di Kota Yogyakarta

Berdasarkan karakteristik rombongan wisatawan dengan lamanya kunjungan menunjukkan bahwa lama kunjungan selama 3-4 hari (70 persen/42 rombongan), wisatawan yang menikmati wisata selama 1-2 hari (15 persen/9 rombongan), dan wisata menikmati selama 5 hari atau lebih (15 persen/9 rombongan).

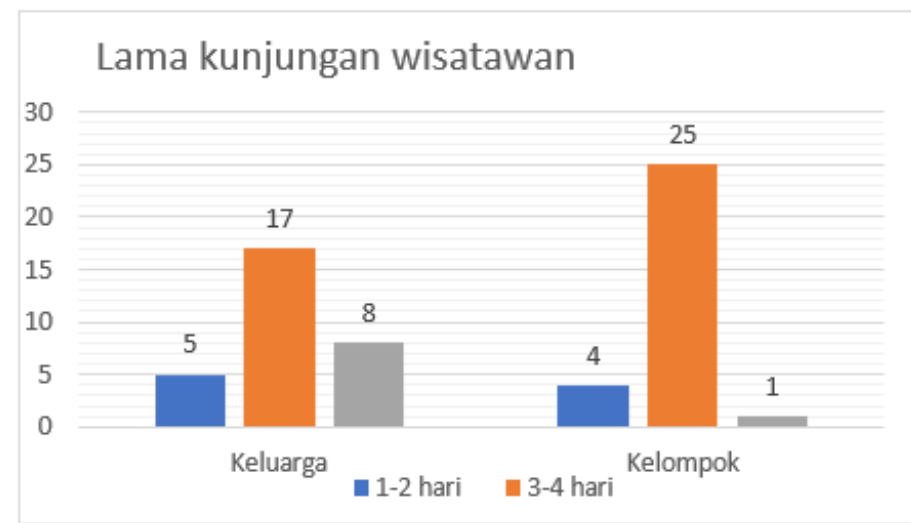

Gambar 4

Diagram Lama Kunjungan Wisatawan

Selama Berwisata

Rombongan wisatawan dengan lama kunjungan wisata selama 3-4 hari, mencapai 25 rombongan kelompok, sedangkan rombongan keluarga dengan 3-4 hari mencapai 17 rombongan keluarga. Wisatawan yang menikmati wisata selama 5-6 hari lebih dominan pada rombongan keluarga daripada rombongan kelompok. Sedangkan wisatawan dengan lama kunjungan 1-2 hari mendekati sama di antara rombongan keluarga dan rombongan kelompok. Hal ini dikarenakan tidak memiliki waktu yang banyak untuk berlibur melainkan untuk refreshing sebentar dari pekerjaan. Ini menunjukkan lama kunjungan ideal yaitu 3-4 hari selama wisata di Yogyakarta.

3. Kunjungan Wisata, Sumber Informasi

Kunjungan wisata yang dimaksud adalah kunjungan sementara waktu dan pada akhirnya akan kembali ke tempat asal wisatawan semula. Ada 2 elemen yang penting yaitu perjalanan itu sendiri dan tinggal di tempat tujuan dengan sementara selama berbagai aktivitas wisatanya. Objek wisata yang dikunjungi karena suasananya baru, keinginan untuk mengetahui atau budaya. 


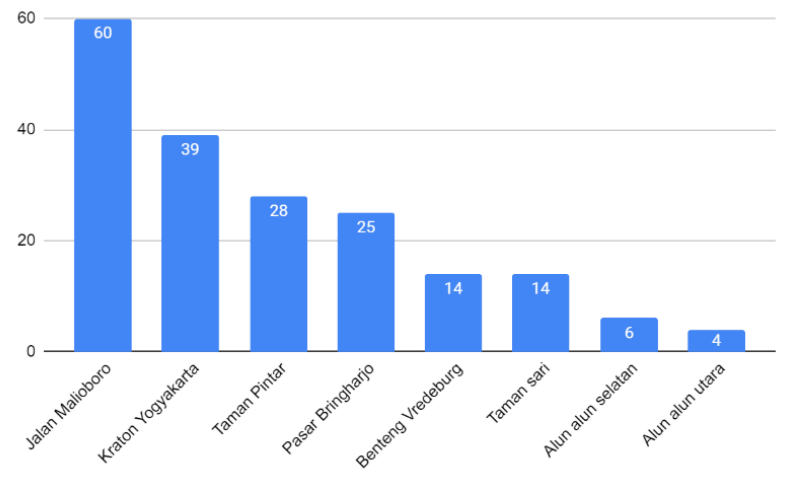

Gambar 5

Diagram Kunjungan Wisatawan

Berdasarkan data lapangan, hasil responden wisatawan sangat tertarik dengan sepanjang jalan Malioboro di Kawasan Malioboro. Malioboro juga berdekatan dengan objek wisata lainnya yaitu Pasar Bringharjo, Benteng Vredeburg, Keraton Yogyakarta, Taman Pintar, Taman Sari, dan lain-lainnya.
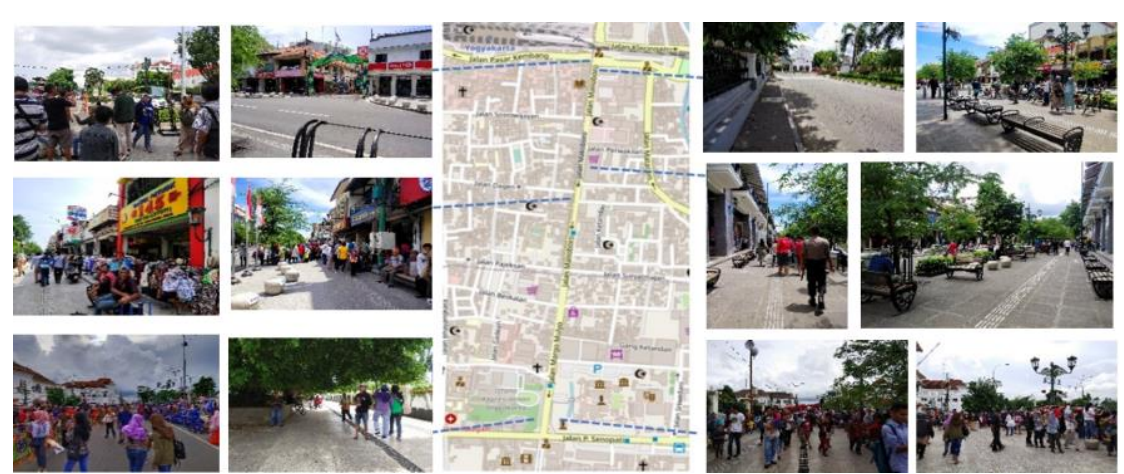

Gambar 6

Jalan Malioboro

Kawasan Malioboro merupakan kawasan perdagangan dengan layanan yang diberikan oleh berbagai tempat wisata yang menarik wisatawan. Jalan Malioboro berbentuk sumbu linier yang membentang lurus sepanjang kurang lebih 2 kilometer.

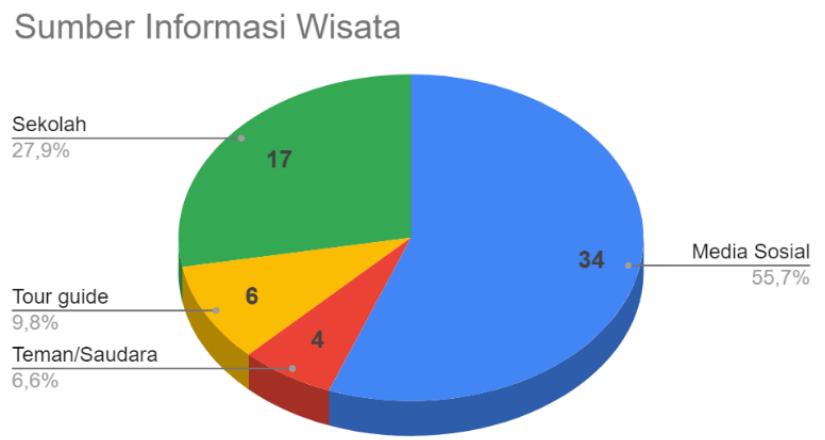

Sumber 7

Sumber Informasi Wisata 
Rombongan wisata berdasarkan sumber informasi, menunjukkan referensi dari media sosial merupakan sumber informasi yang banyak digunakan oleh wisatawan (55,7 persen/34 kelompok), disusul sekolah atau kegiatan sekolah (27,9 persen/17 kelompok), tour guide (9,8 persen/6 kelompok) dan sumber informasi dari teman atau saudara (6,6 persen/4 kelompok).

\section{B. Persepsi dan Pola Pergerakan Wisatawan}

\section{Persepsi Wisatawan}

Suatu kegiatan perjalanan wisata ke suatu daerah, tentunya wisatawan memiliki gambaran pemikiran mengenai daerah tujuan tersebut. Begitu pula wisatawan yang ingin mengunjungi Yogyakarta. Sehingga para wisatawan memiliki pendapatnya mengenai Yogyakarta seperti apa.

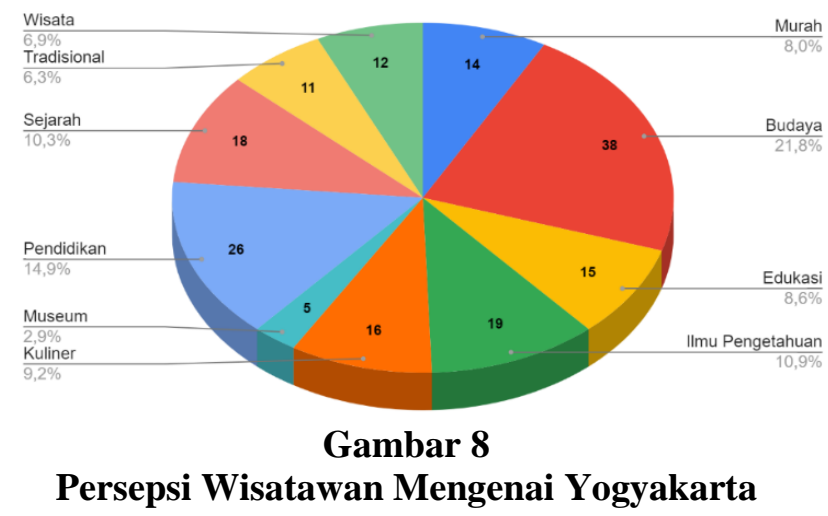

Selain kota Yogyakarta merupakan kota budaya dan sejarah, kota ini juga dikenal dengan kota pelajar di kalangan masyarakat mancanegara. Kota yang memiliki banyak perguruan tinggi dan universitas terutama yang paling diketahui wisatawan yaitu Universitas Gadjah Mada. Terdapat lagi universitas atau perguruan tinggi unggulan yang lain di Yogyakarta, memungkinkan banyak banyak pelajar dari berbagai daerah untuk belajar di perguruan tinggi tersebut.

"[...] Tujuan studi kali ini kami mengunjungi ke Perguruan Tinggi Negeri di Yogyakarta. [...]" (Af, P, Wawancara 20 Februari 2020)

“[...] berikutnya kami kunjungan ke Universitas Gadjah Mada, [...]” (Ns, P, Wawancara 23 Februari 2020)

2. Persepsi Wisatawan terhadap Fasilitas Umum

Persepsi mereka untuk kondisi fasilitas umum yang ada di objek wisata Malioboro sudah cukup baik dan perlunya peningkatan dan perbaikan demi keindahan dari objek wisata ini. Pihak pengelola dan pihak pemerintah dalam mengolah wisata ini perlu ditingkatkan lagi seperti fasilitas tempat duduk, tempat berteduh, kamar kecil/WC, dan lainnya.

3. Persepsi Wisatawan terhadap Daya Tarik Objek Wisata

Sebagian besar mengagumi dengan objek wisata yang terdapat di kawasan Malioboro karenakan objek wisata ini memiliki daya tariknya sendiri yang tidak dijumpai di wisata daerah lain, seperti wisata budaya, sejarah, pendidikan yang 
berdekatan dengan wisata belanja. Selain itu bangunan yang mencirikan arsitektur kolonial belanda di sepanjang pedestrian Jalan Malioboro.

4. Persepsi Wisatawan terhadap Kebersihan Objek Wisata

Persoalan kebersihan di lokasi objek peneliti sudah baik, hanya perlunya ditingkatkan lagi kebersihan dan fasilitas seperti tempat sampah yang selalu penuh dengan sampah. Perlunya penambahan jumlah tempat sampah di titik-titik setiap objek wisata ini. menurut mereka kurangnya tempat sampah di titik wisata memyebabkan sebagian wisastawan membuang sampah sembarangan. Hal ini terjadi dikarenakan kebiasaan perilaku wisatawan yang kurang akan kebersihan lingkungan selama berwisata.

5. Persepsi Wisatawan terhadap Kondisi Keamanan

Sebagian wisatawan merasa cukup baik aman pada kawasan Malioboro terutama pada Jalan Malioboro dan sudah masuk standar keamanan wisatawan. Bagi wisatawan lain tingkat keamanan di lokasi wisata harus ditingkatkan lagi seperti penyeberangan jalan yang dikhususkan untuk pejalan kaki. Selain itu perlunya pemerintah terutama dinas perhubungan untuk menjaga fasilitas pedestrian yang diperuntukkan pejalan kaki bukan tempat parkir kendaraan atau akses kendaraan.

6. Persepsi Wisatawan terhadap Kemudahan Mendapat Informasi

Informasi tentang objek wisata ini dapat beragam pendapat, ada yang merasa sudah tahu mengenai objek wisasta, ada juga merasa sulit untuk mendapatkan informasi tentang objek yang ada di Malioboro. Informasi yang kurang ini meliputi jam operasional tempat wisata. Hal ini terjadinya kurangnya promosi dan informassi yang mereka peroleh. Berdasarkan informasi yang didapat, ada beberapa wisatawan yang sudah tahu adanya aplikasi seperti Visting Jogja, Jogja Istimewa atau media sosial mengenai wisata apa saja yang didapatkan selama berwisata di kawasan Malioboro.

7. Pola Pergerakan Wisatawan

Pola pergerakan wisata yang dikemukakan oleh Lau dan McKercher (2006) ditentukan mendekati seluruh pola aktivitas wisata yang terjadi di kawasan Malioboro. kelompok keluarga memilih mobil, baik mobil rental maupun mobil pribadi. Untuk kenyamanan akses lebih cepat mengunjungi objek wisata di kawasan. Hasil wawancara pada rombongan kelompok yaitu kendaraan bus sekolah atau bus pariwisata yang dapat menampung banyak penumpang dalam sekali perjalanan. 


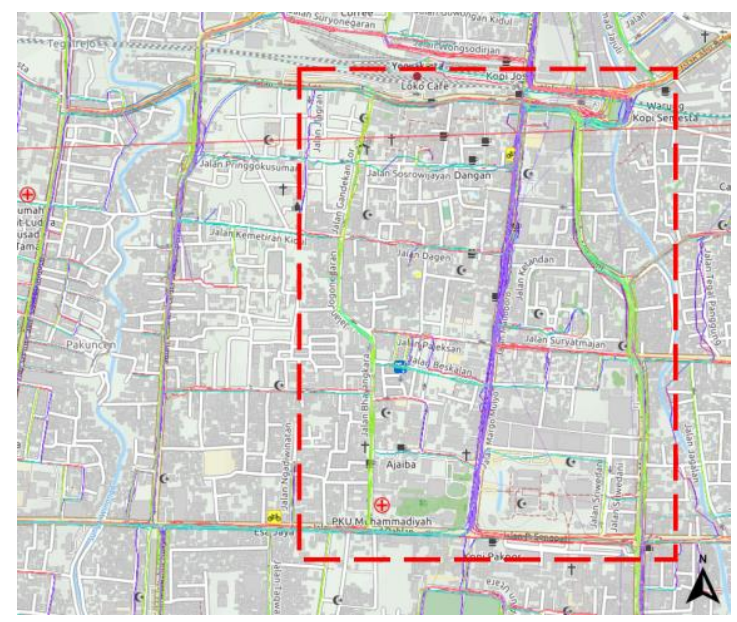

\section{Gambar 9}

Pola Pergerakan Wisatawan pada Kawasan Malioboro

Berdasarkan beberapa pola pergerakan menurut Lau \& McKercher dalam (Sukmaratri, 2013) pola pergerakan dibagi 3 jenis pattern yaitu single pattern, multi pattern, dan complex pattern. Pola pergerakan dalam jenis pattern terbagi 6 jenis yaitu single point, base point, stopover, chaining loop. Destination region loop, dan complex neighbourhood.

a) Single Point

Pergerakan single point, pergerakan wisatawan ke lokasi yang hanya memiliki satu tujuan tanpa harus mengunjungi destinasi lain dan menggunakan rute yang sama untuk kembali ke tempat asalnya. Pergerakan ini langsung mengarah ke tujuan wisata.

“[...] Parkir motornya di Abu Bakar Ali. Tujuan kami jalan jalan sepanjang Malioboro aja hari ini (karena Selasa Wage) [...]" (Rd, L, Wawancara 18 Februari 2020). 
Tabel 3

Pola Pergerakan Single Point Pada

Objek Penelitian

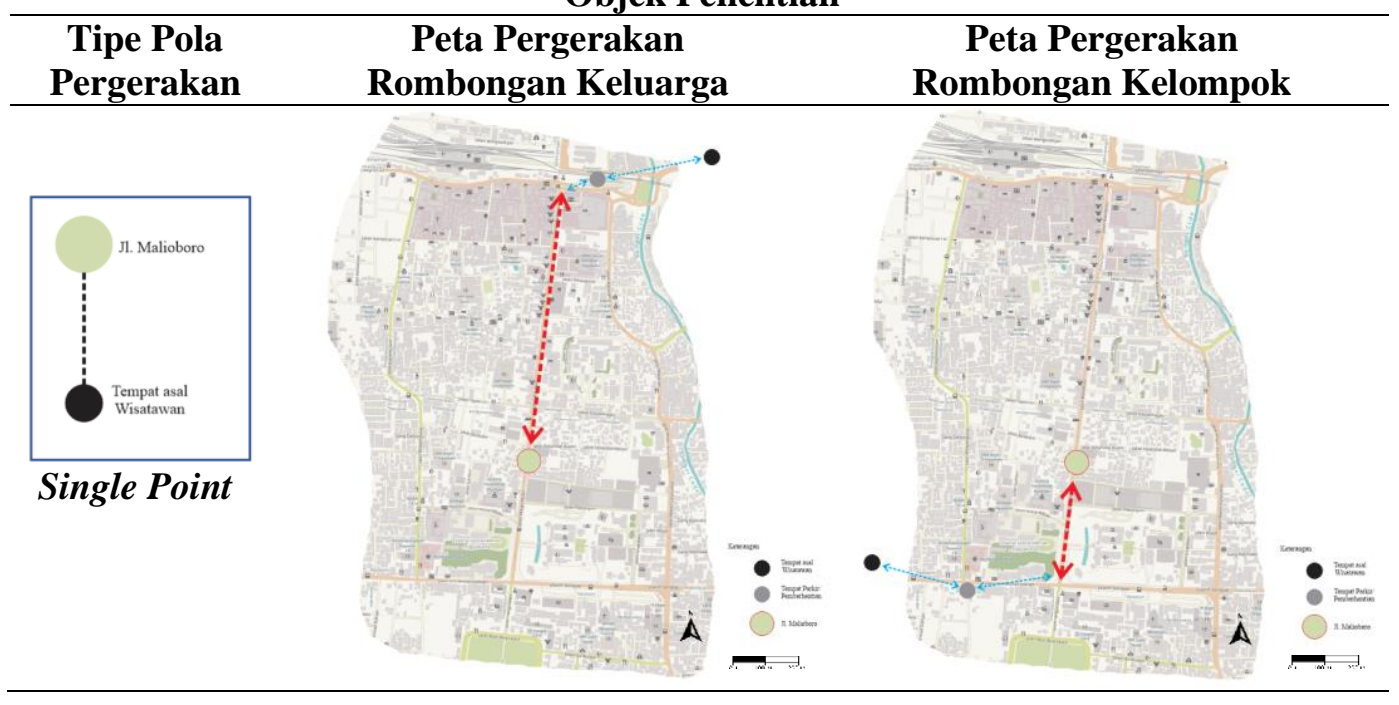

Rombongan kelompok dan rombongan keluarga yang hanya mengunjungi satu titik wisata yaitu jalan Malioboro untuk menikmati selasa wage. Selasa wage yang merupakan acara rutin setiap 35 hari sekali. Acara rutin ini bertujuan sepanjang jalan Malioboro terbebas dari pedagang kaki lima yang berjualan.

b) Base Site

Wisatawan memulai perjalanannya dari tempat pemberangkatannya, kemudian menuju ke tujuan utama, dan kemudian melanjutkan ke tujuan sekunder di daerah tertentu.

“[...] dekat mas dari Klaten ke Jogja nya maka kami tidak menginap. Jika parkir di Ramai mall, karena tujuan kami jalan Malioboro sampai disini (pasar Beringharjo) [...]" (Ab, L, Wawancara 18 Februari 2020).

"[...] sampai Jogja langsung check-in hotel, letak barang dan istirahat sebentar lalu jalan ke Malioboro di malam hari, ingin merasa suasana Malioboro di malam hari, lalu ke alun alun selatan dengan mobil [...]" (Mg, P, Wawancara 29 Februari 2020). 
Tabel 4

Pola Pergerakan Base Site pada Objek Penelitian

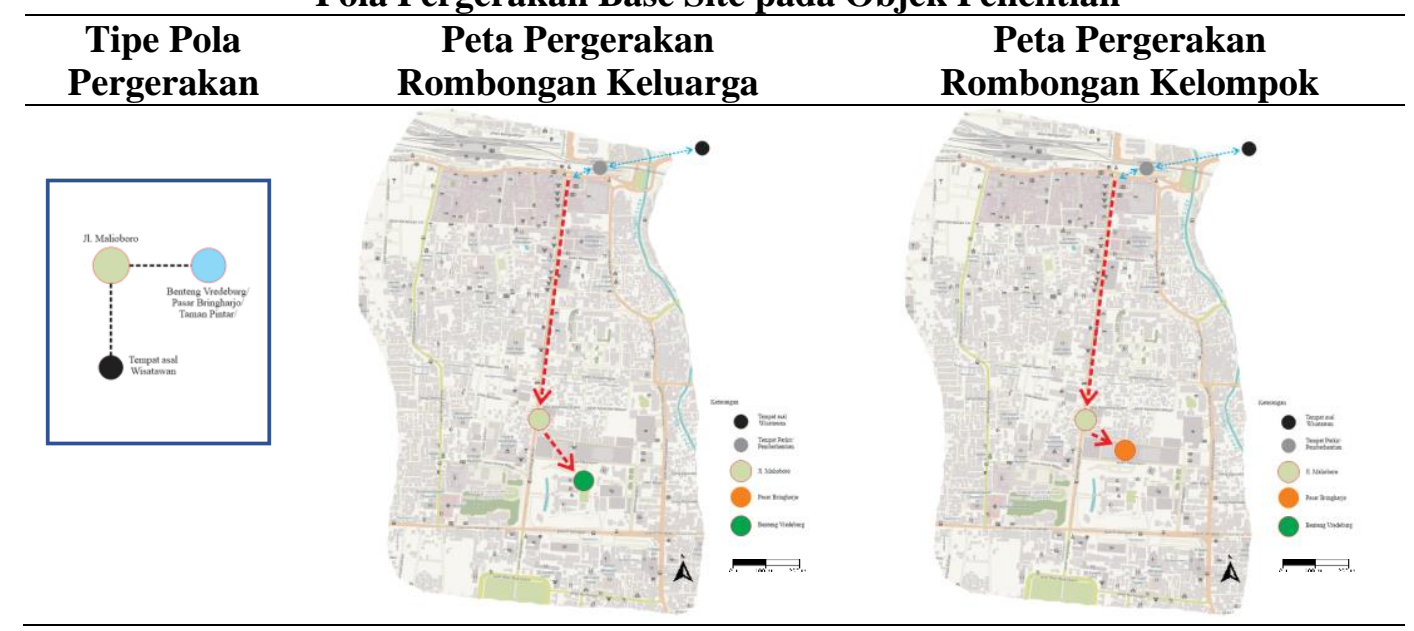

Pola base site pada wisatawan yang melakukan perjalanannya bermula dari asal wisatawan menuju Malioboro, kemudian menuju tempat parkir yang tersedia di kawasan Malioboro. Jalan santai sepanjang perjalanan dengan menikmati suasana Yogyakarta yaitu kuliner, batik, barang kerajinan, dan lainlainnya. Perjalanan selanjutnya menuju wisata belanja di pasar Bringharjo, wisata museum Benteng Vredeburg, maupun wisata edukasi yaitu Taman Pintar.

c) Stopover

Dalam proses pergerakan, yaitu cara wisatawan yang menargetkan dua atau lebih tujuan bergerak, Taman Pintar, Benteng Vredeburg dan jalan Malioboro, dimana wisata Taman Pintar, Benteng Vredeburg sebagai destinasi sekunder dan jalan Malioboro merupakan destinasi utama.

“[...] pertama menuju wisata Taman Pintar karena anak pertama ingin bermain ke Taman Pintar. Setelah itu pergi ke Benteng Vredeburg dan terakhir jalan sepanjang jalan Malioboro. [...]" (Di, P, Wawancara 22 Februari 2020).

"[...] Wisata akan di kunjungi yaitu Museum Vredeburg, dan wisata terakhir belanja di Malioboro. [...]" (Ii, P, Wawancara 25 Februari 2020). 
Tabel 5

Pola Pergerakan Stopover Pada Objek Penelitian

\begin{tabular}{|c|c|c|c|c|}
\hline $\begin{array}{l}\text { Tipe Pola } \\
\text { Pergerakan }\end{array}$ & $\begin{array}{c}\text { Peta Pergerakan } \\
\text { Rombongan Keluarga }\end{array}$ & & $\begin{array}{c}\text { Peta Pergerakan } \\
\text { Rombongan Kelompok }\end{array}$ & ok \\
\hline$\hat{\hat{\theta}}$ & $y=\dot{A}$ & 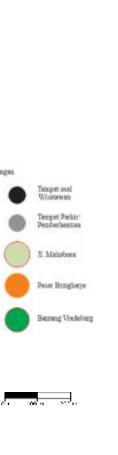 & $\left.\right|_{-\pi} ^{a}$ & $\begin{array}{l}0 . \\
0= \\
0= \\
0= \\
0=\end{array}$ \\
\hline
\end{tabular}

Kegiatan pada rombongan kelompok sebelum mengunjungi Malioboro adalah Taman Pintar. Kegiatan setelah Taman Pintar, rombongan dapat belanja dan jalan sepanjang jalan Malioboro bersama teman-teman atau berkelompok.

Rombongan keluarga tujuan utama lebih dominan wisata belanja di Pasar Bringharjo yang terkenal dengan barang-barang dan pakaian yang terjangkau, selain terjangkau juga terdapat banyak varian di dalam Pasar Bringharjo.

d) Chaining Loop

Cara wisatawan menuju destinasi wisata dimulai dari titik awal wisatawan, kemudian menuju kawasan Malioboro, kemudian Jalan Malioboro, Pasar Bringharjo, Benteng Vredeburg, dan terakhir Taman Pintar untuk aktivitas wisata, kemudian wisatawan kembali ke tempat asalnya.

"[...] dari Malioboro mall lalu kesini (Pasar Beringharjo) sudah beli batik dan baju untuk pakai pribadi. Ini mau pergi ke alun alun dan Taman Sari. [...]" (Sr, P, Wawancara 22 Februari 2020).

"[...] Sudah jalan Malioboro, Ini mau ke taman pintar biar tambah wawasan dan bermain, mas. Habis itu ke Keraton Yogyakarta. Itu aja si mas wisata kami. [...]” (Mj, L, Wawancara 22 Februari 2020). 
Tabel 6

Pola Pergerakan Chaining Loop pada Objek Penelitian

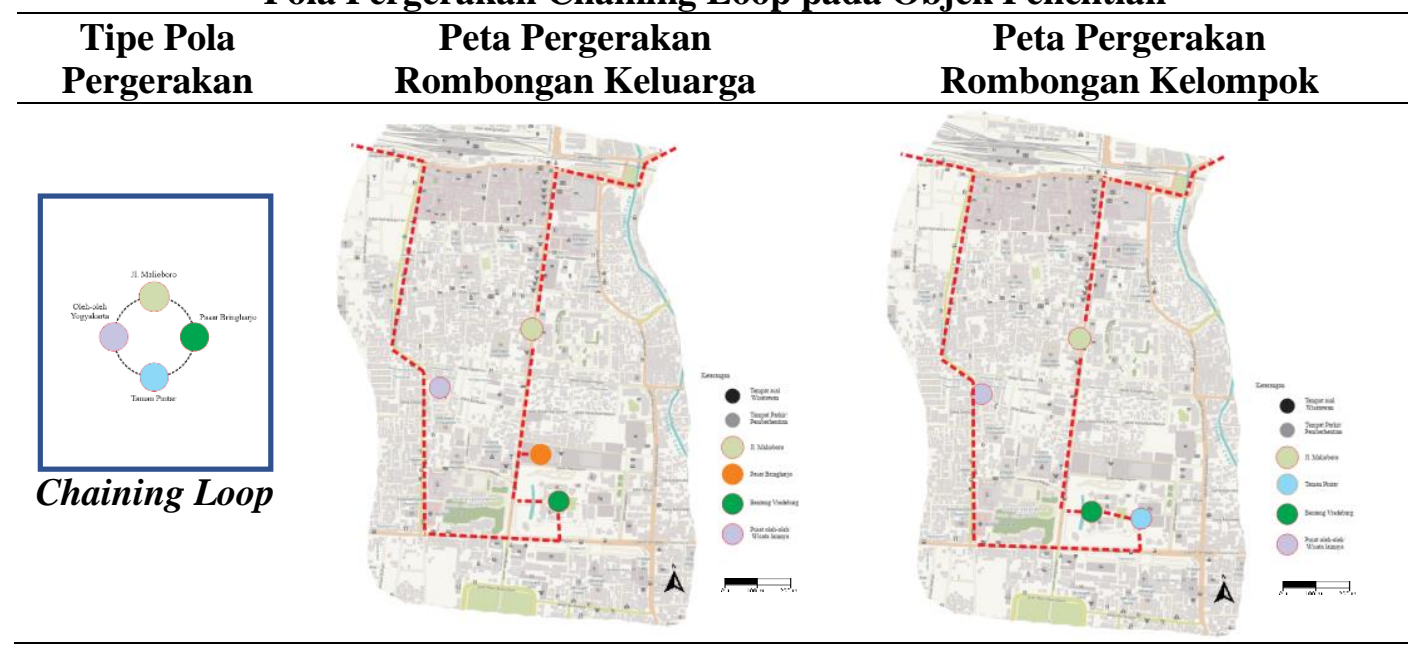

Responden pada kelompok berwisata mengunjungi Taman Pintar, kemudian menuju Benteng Vredeburg setelah itu mereka mengunjungi penjual souvenir sepanjang Malioboro, dan mengunjungi oleh-oleh makanan khas Yogyakarta sebelum wisatawan kembali ke daerah asalnya.

\section{Kesimpulan}

Motivasi wisatawan melakukan perjalanan adalah relaksasi atau hiburan ketika berkunjung ke objek wisata. Keinginan untuk penyegaran diri dari aktivitas keseharian atau pekerjaan sehingga memulihkan kembali semangat mental dan fisik. Pola pergerakan wisatawan pada rombongan keluarga adalah base site dengan perjalanan dari Malioboro menuju wisata belanja, kuliner dan edukasi dan kembali ke asalnya. Pola wisatawan pada rombongan kelompok terutama kelompok dengan status pelajar yaitu stopover dengan objek wisata yang dikunjungi adalah pendidikan. Wisatawan dipengaruhi oleh beberapa aktivitas dan faktor, salah satunya aktivitas adalah liburan, aktivitas sekolah. Faktor pergerakan juga dipengaruhi waktu dan cuaca, aktivitas wisatawan kelompok dimulai dengan aktivitas kunjungan wisata budaya di pagi hari. Hal ini wisatawan mengikuti prosedur jam operasional yang terdapat pada tempat wisata dan memiliki waktu terbatas. Perjalanan dilanjuti dengan perjalanan bebas atau santai di sepanjang jalan Malioboro dengan aktivitas belanja dan kuliner. Faktor lainnya adalah aksesibilitas yang masih kurang dikarenakan jarak tempat parkir menuju tempat objek wisata cukup jauh. Sehingga pengunjung mencari transportasi lain seperti transportasi online untuk langsung menuju ke objek wisata. Keterbatasan kantong parkir dekat dengan objek wisata membuat rombongan keluarga lebih memilih tempat parkir yang dekat dengan objek wisata yang dituju dengan harga yang cukup mahal.

Pada tahapan penelitian selanjutnya, dapat dilakukan analis lebih lanjut terkait pengembangan titik-titik generator di sekitar objek wisata di kawasan Malioboro. Kelanjutan dari penelitian ini akan digunakan sebagai input dalam simulasi perilaku wisatawan dalam berwisata. Permodelan ini digunakan sebagai pendekatan perencanaan 
Persepsi dan Pola Pergerakan Wisatawan Di Kota Yogyakarta Kasus: Kawasan Malioboro

kawasan yang dapat menciptakan suasana yang memuaskan bagi wisatawan dalam kriteria pergerakan secara efisien dan efektif. 


\section{BIBLIOGRAFI}

Arikunto, S. (2014). Metode penelitian kuantitatif, kualitatif, dan kombinasi (mixed methods). Bandung: Alfabeta. Google Scholar

Ario Gesang, L. (2021). Analisis Pola Pergerakan Masyarakat Kota Terhadap Efektifitas Pelayanan Angkutan Umum (Bemo)(Studi Kasus Kota Mataran). Universitas_Muhammadiyah_Mataram. Google Scholar

Chaniago, Y. (2015). Inbound tour (3rd ed). Jogjakarta: PT Kanisiyus. Google Scholar

DIY, D. P. (2019). Statistik Kepariwisataan DIY 2018. Dinas Pariwisata DIY. Google Scholar

Dwi P, W. I. (2018). Analis Perbandingan Biaya Moda Transportasi Pribadi Dengan Moda Transportasi Umum (Bus Trans Sidoarjo) Di Kota Sidoarjo Studi Kasus: Jalan Raya Surabaya Sidoarjo. Universitas 17 Agustus 1945. Google Scholar

Lusiana, U. (2012). Penerapan Kurva Kalibrasi, Bagan Kendali Akurasi Dan Presisi Sebagai Pengendalian Mutu Internal Pada Pengujian Cod Dalam Air Limbah. Biopropal Industri Vol. 3 No. 1 Juni 2012 1, 8. Google Scholar

Papilo, P. (2012). Pengukuran Kinerja Organisasi dengan Penerapan Metode IPMS yang Terintegrasi dengan Metode SMART System (Studi Kasus: Fakultas "X"). Seminar Nasional Teknologi Informasi Komunikasi Dan Industri. Google Scholar

Ramadhani, Y. (2015). Pengaruh Persepsi Mahasiswa Tentang Profesi Guru Dan Minat Menjadi Guru Terhadap Indeks Prestasi Mahasiswa Semester Enam Prodi Administrasi Perkantoran Fakultas Ekonomi Unimed Ta 2014/2015. Unimed. Google Scholar

Shafaruddin, R. (2013). Persepsi Mahasiswa Terhadap Upt. Perpustakaan Universitas Tanjungpura. Tanjungpura University. Google Scholar

Siregar, H. H. (2016). Analisis Kualitas Faktual Sebagai Salah Satu Alat Evaluasi Penentu Kualitas Ruang Terbuka Publik di Kota Bandung. TEMU ILMIAH IPLBI, E005-E009. Google Scholar

Sofi, C., \& Susilowati, M. H. D. (2017). Faktor Pengaruh Pola Pergerakan Wisatawan di Kota dan Kabupaten Tegal. 8th Industrial Research Workshop and National Seminar. Google Scholar

Sugiyono, S. (2016). Metode Penelitian Kuantitatif, Kualitatif dan Kombinasi (Mixed Methods) (M.. Sutopo, Ed.). Bandung: ALFABETA. Cv. Google Scholar

Sukmaratri, M. (2013). Faktor Pembentuk Pola Pergerakan Wisatawan Pada Destinasi Wisata Alam di Kabupaten Malang. Universitas Brawijaya. Google Scholar 
Suwena, I. K., \& Widyatmaja, I. G. N. (2017). Pengetahuan Dasar Ilmu Pariwisata (Revisi). Pustaka Larasan. Google Scholar

Widyastuti, H., Marsoyo, A., \& Setiawan, B. (2019). Analisis Preferensi Dan Rute Destinasi Pariwisata Pantai Di Daerah Istimewa Yogyakarta. Jurnal Tata Kota Dan Daerah, 10(2), 67-76. Google Scholar

\section{Copyright holder:}

Tatang Salim, Deva Fosterharoldas Swasto (2022)

First publication right:

Jurnal Syntax Admiration

This article is licensed under:

(c) (i) () 